\title{
THE PHOSPHATIDES OF HUMAN PLASMA. II. ABNORMALITIES ENCOUNTERED IN THE NEPHROTIC SYNDROME*
}

\author{
By WILLIAM H. R. NYE† AND CHRISTINE WATERHOUSE \\ (From the Department of Medicine, University of Rochester School of Medicine and Dentistry, \\ Rochester, N.Y.)
}

(Submitted for publication October 4, 1960; accepted March 9, 1961)

Abnormalities in the plasma lipids have been correlated with the nephrotic syndrome for many years. Zone (3) and immunoelectrophoresis (4), Cohn fractionation (5), and ultracentrifugal analysis $(6,7)$ have all confirmed increased concentrations of certain plasma lipoproteins. Recent studies by Baxter, Goodman and Havel (7) have documented abnormal proportions of cholesterol, triglyceride and phospholipid in the lipoprotein classes.

Neither the course of events leading to these abnormalities nor their role in the manifestations of the nephrotic syndrome is well understood. Data on the phosphatides in this condition have been limited to alterations in the levels of the lipid phosphorus in the plasma and in the lipoprotein classes (7), and to changes in the incorporation of $\mathrm{P}^{32}$ into the lipid phosphorus of plasma (8). A change in the composition of the plasma phosphatides has been postulated on the basis of these $\mathrm{P}^{32}$ experiments. This study was undertaken to investigate, by the use of chromatographic techniques, the individual phosphatides in the plasma of patients with the nephrotic syndrome.

\section{METHODS}

Hospitalized patients with the nephrotic syndrome were studied on the medical and pediatric wards of Strong Memorial Hospital. Venipuncture was performed in the fasting state (except for plasmas no. 7, 18 and 21, Tables I and II, which were obtained immediately after light lunches) and blood was collected in a bottle containing potassium oxalate. Plasma separation, lipid extraction, and quantitative paper and column chromatography were performed as previously described (9). Serum cholesterol and serum albumin were determined in the Clinical Chemistry Laboratory of the University of Rochester Medical Center by the method of Bloor (10)

* Some of the data have been reported in abstract form $(1,2)$.

$\dagger$ Postdoctoral Research Fellow of the National Heart Institute. and by electrophoresis with a Spinco apparatus at $\mathrm{pH}$ 8.6, respectively.

Preparative ultracentrifugation of plasma was carried out as described by Havel, Eder and Bragdon (6). Plasma densities were adjusted with solutions of $\mathrm{KBr}$ and $\mathrm{NaCl}$ to yield the following density (D) classes: $<1.019,<1.063$, and $>1.063$. The components of the class D 1.019-1.063 were calculated by difference whenever feasible. Separation was accomplished in a Spinco model L ultracentrifuge with a 40 rotor, with $105,400 \mathrm{G}$ at the tube centers for 22 hours at $2^{\circ} \mathrm{C}$. The supernatant layer of each tube was removed by pipet and was transferred to a $100 \mathrm{ml}$ extraction tube. Lipid adhering to the tube cap was washed into the extraction tube with $0.15 \mathrm{~N}$ saline solution. After the entire supernatant layer and the beginning of the clear intermediate zone had been transferred, the plastic ultracentrifuge tube was cut with scissors and the upper portion of it was added to the extraction tube. The bottom of the ultracentrifuge tube, containing the infranate and the remainder of the clear zone, was placed in a second extraction tube. Lipid extraction was performed with $29 \mathrm{ml}$ methanolchloroform $25: 4$ ( $\mathrm{vol} / \mathrm{vol}$ ), followed by $15 \mathrm{ml}$ methanolchloroform $1: 1$ used three times.

The first three extractions were at $60^{\circ} \mathrm{C}$ for 2 minutes each, and the fourth extraction was for 1 hour at $60^{\circ} \mathrm{C}$. After adding benzene, the pooled extracts were taken to dryness with a rotary vacuum evaporator. The lipids were re-extracted with chloroform, leaving behind a large amount of residue, presumably composed mostly of $\mathrm{KBr}$ and perhaps some $\mathrm{NaCl}$. Further preparation of each extract, and phosphatide analysis by quantitative paper chromatography were carried out as previously described (9).

While lipid extracts of whole plasma have always dried to a constant weight of $60^{\circ} \mathrm{C}$ under a stream of nitrogen in less than 1 hour, and have then appeared solid, extracts of the density classes have never become more than partially solidified after 1 hour of drying, at which time isoamyl alcohol-benzene 1:1 was added, and chromatography was carried out.

\section{RESULTS}

Distribution of major phosphatides in whole plasma. Table I shows the data on plasma samples obtained from each patient during the study, and Table II shows the data on serial plasma sam- 
PLASMA PHOSPHATIDES IN THE NEPHROTIC SYNDROME

TABLE I

Data on plasma samples of all patients with the nephrotic syndrome

\begin{tabular}{|c|c|c|c|c|c|c|c|c|c|c|c|c|}
\hline \multirow[b]{2}{*}{ Plasma } & \multirow[b]{2}{*}{ Patient } & \multirow{2}{*}{$\begin{array}{l}\text { Chloro- } \\
\text { form-- } \\
\text { soluble P }\end{array}$} & \multirow[b]{2}{*}{$\begin{array}{l}\text { Total } \\
\text { lipid }\end{array}$} & \multirow[b]{2}{*}{$\begin{array}{l}\text { Appearance } \\
\text { of plasma }\end{array}$} & \multirow{2}{*}{$\begin{array}{c}\text { Serum } \\
\text { choles- } \\
\text { terol }\end{array}$} & \multirow[b]{2}{*}{$\begin{array}{l}\text { Serum } \\
\text { albumin }\end{array}$} & \multirow[b]{2}{*}{$\begin{array}{c}\text { Lyso- } \\
\text { lecithin }\end{array}$} & \multirow[b]{2}{*}{$\begin{array}{c}\text { Sphingo- } \\
\text { myelin }\end{array}$} & \multirow[b]{2}{*}{ Lecithin } & \multicolumn{3}{|c|}{ Phosphatide phosphorus } \\
\hline & & & & & & & & & & $\begin{array}{c}\text { Lyso- } \\
\text { lecithin }\end{array}$ & $\begin{array}{c}\text { Sphingo- } \\
\text { myelin }\end{array}$ & Lecithin \\
\hline & & $\mu g / m l$ & $m g / m l$ & & $\mathrm{mg} / 100 \mathrm{ml}$ & $\mathrm{g} / 100 \mathrm{ml}$ & & $P / m l$ plasn & Gro & $A^{\%}$ & $\%$ & $\%$ \\
\hline \multirow[t]{2}{*}{$\begin{array}{l}1 \\
2 \\
3 \\
4 \\
5 \\
6 \\
7 \\
8 \\
9\end{array}$} & $\begin{array}{l}\text { F.G. } \\
\text { E.J. } \\
\text { J.S. } \\
\text { D.C. } \\
\text { M.D. } \\
\text { G.C. } \\
\text { M.L. } \\
\text { B.W. } \\
\text { H.C. }\end{array}$ & $\begin{array}{r}154 \\
119 \\
135 \\
82 \\
173 \\
118 \\
83 \\
217 \\
187\end{array}$ & $\begin{array}{l}16.56 \\
12.6 \\
14.75 \\
11.3 \\
21.3 \\
13.5 \\
14.8 \\
28.2 \\
20.6\end{array}$ & $\begin{array}{c}\text { clear } \\
\text { clear } \\
\text { clear } \\
\text { clear } \\
\text { mod. lact. } \\
\text { clear } \\
\text { lact. } \\
\text { lact. } \\
\text { slightly lact. }\end{array}$ & $\begin{array}{l}365 \\
452 \\
522 \\
468 \\
620 \\
420 \\
564 \\
890 \\
880\end{array}$ & $\begin{array}{l}1.4 \\
1.4 \\
2.4 \\
1.1 \\
2.4 \\
0.6 \\
2.1\end{array}$ & $\begin{array}{r}26.9 \\
16.5 \\
6.1 \\
10.7 \\
20.6 \\
26.1 \\
17.8 \\
27.4 \\
21.6\end{array}$ & $\begin{array}{l}32.5 \\
27.4 \\
21.2 \\
20.1 \\
39.3 \\
29.5 \\
25.1 \\
54.0 \\
54.8\end{array}$ & $\begin{array}{c}45.2 \\
20.6 \\
7.4 \\
37.4 \\
93.6 \\
60.0 \\
16.6 \\
110.0 \\
106.0\end{array}$ & $\begin{array}{l}25.8 \\
25.6 \\
17.6 \\
15.7 \\
13.4 \\
22.6 \\
29.9 \\
14.3 \\
11.8\end{array}$ & $\begin{array}{l}31.1 \\
42.5 \\
61.1 \\
29.5 \\
25.6 \\
25.5 \\
42.1 \\
28.2 \\
30.0\end{array}$ & $\begin{array}{l}43.2 \\
32.0 \\
21.3 \\
54.8 \\
61.0 \\
51.9 \\
28.0 \\
57.5 \\
58.2\end{array}$ \\
\hline & & & & & & & \multicolumn{6}{|c|}{ Group B } \\
\hline \multirow[t]{2}{*}{$\begin{array}{l}10 \\
11 \\
12 \\
13 \\
14\end{array}$} & $\begin{array}{l}\text { L.A. } \\
\text { B.W. } \\
\text { B.W. } \\
\text { L.C. } \\
\text { L.A. }\end{array}$ & $\begin{array}{l}116 \\
262 \\
169 \\
113 \\
141\end{array}$ & $\begin{array}{l}12.0 \\
60.7 \\
49.7 \\
10.1 \\
13.3\end{array}$ & $\begin{array}{l}\text { clear } \\
\text { lact. } \\
\text { lact. } \\
\text { clear } \\
\text { clear }\end{array}$ & $\begin{array}{r}213 \\
1,734 \\
375 \\
432\end{array}$ & $\begin{array}{l}1.1 \\
1.5 \\
1.1\end{array}$ & $\begin{array}{r}10.3 \\
41.8 \\
22.5 \\
15.4 \\
6.7\end{array}$ & $\begin{array}{l}26.2 \\
57.8 \\
38.2 \\
26.1 \\
30.0\end{array}$ & $\begin{array}{r}56.8 \\
140.0 \\
105.2 \\
67.2 \\
67.1\end{array}$ & $\begin{array}{r}11.0 \\
17.5 \\
13.6 \\
14.2 \\
6.4\end{array}$ & $\begin{array}{l}28.1 \\
24.1 \\
23.0 \\
24.0 \\
28.9\end{array}$ & $\begin{array}{l}60.9 \\
58.4 \\
63.4 \\
61.8 \\
64.7\end{array}$ \\
\hline & & & & & & & \multicolumn{6}{|c|}{ Normal distribution } \\
\hline \multirow[t]{3}{*}{$\begin{array}{l}15 \\
16\end{array}$} & $\begin{array}{l}\text { L.C. } \\
\text { J.S. }\end{array}$ & $\begin{array}{r}158 \\
90\end{array}$ & $\begin{array}{l}13.6 \\
10.2\end{array}$ & $\begin{array}{l}\text { clear } \\
\text { clear }\end{array}$ & $\begin{array}{l}400 \\
364\end{array}$ & 2.5 & $\begin{array}{c}10.6 \\
7.9\end{array}$ & $\begin{array}{l}31.6 \\
16.9\end{array}$ & $\begin{array}{c}107.0 \\
46.1\end{array}$ & $\begin{array}{r}7.1 \\
11.1\end{array}$ & $\begin{array}{l}21.1 \\
23.8\end{array}$ & $\begin{array}{l}71.8 \\
65.1\end{array}$ \\
\hline & & & & & & & \multicolumn{6}{|c|}{ Ranges of normal values } \\
\hline & & & & & & & $\begin{array}{l}5.4- \\
9.5\end{array}$ & $\begin{array}{l}12.4- \\
20.6\end{array}$ & $\begin{array}{l}30.9- \\
71.7\end{array}$ & $\begin{array}{l}6.9- \\
11.7\end{array}$ & $\begin{array}{l}17.6- \\
24.3\end{array}$ & $\begin{array}{l}64.0- \\
73.2\end{array}$ \\
\hline
\end{tabular}

ples of two of these patients. In ten samples in which the level of cholesterol was elevated and that of albumin was depressed, the level of chloroformsoluble phosphorus was normal. The level of chloroform-soluble phosphorus was raised in all other plasmas.

Elevations in the level of one, two, or all three individual major phosphatides were found, regardless of the levels of the chloroform-soluble phosphorus, in all but two plasmas. In the latter (nos. 16 and 22) depressed or normal, but not elevated, levels of one or more phosphatides were found. However, when the proportions among the major phosphatides were considered, a single pattern of

TABLE II

Data on serial plasma samples of two patients with the nephrotic syndrome

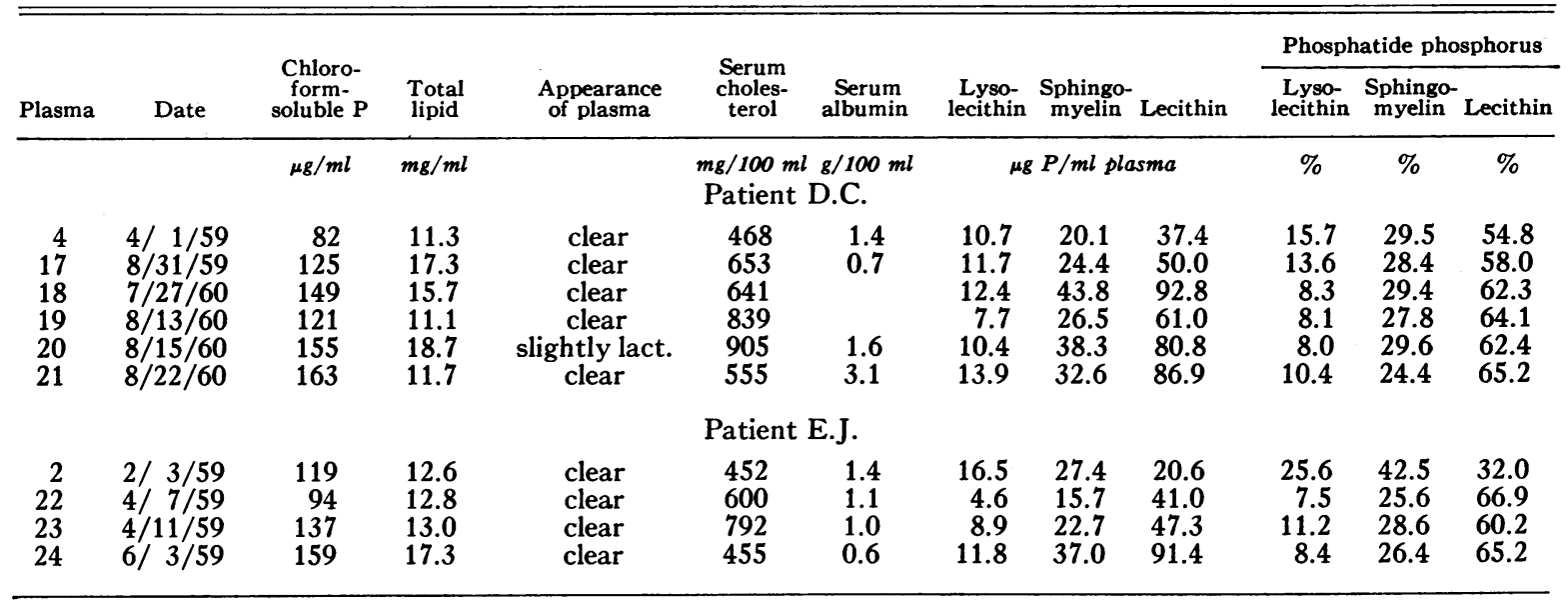


TABLE III

Phosphatide analyses of lipoprotein density classes

\begin{tabular}{|c|c|c|c|c|c|c|c|c|c|}
\hline \multirow[b]{2}{*}{ Plasma } & \multirow[b]{2}{*}{ Patient } & \multirow[b]{2}{*}{$\begin{array}{l}\text { Chloroform- } \\
\text { soluble P }\end{array}$} & \multirow[b]{2}{*}{$\begin{array}{l}\text { Density } \\
\text { class }\end{array}$} & \multirow[b]{2}{*}{$\begin{array}{c}\text { Lyso- } \\
\text { lecithin }\end{array}$} & \multirow[b]{2}{*}{$\begin{array}{l}\text { Sphingo- } \\
\text { myelin }\end{array}$} & \multirow[b]{2}{*}{ Lecithin } & \multicolumn{3}{|c|}{ Phosphatide phosphorus } \\
\hline & & & & & & & $\begin{array}{l}\text { Lyso- } \\
\text { lecithin }\end{array}$ & $\begin{array}{c}\text { Sphingo- } \\
\text { myelin }\end{array}$ & Lecithin \\
\hline & & $\mu g / m l$ & & \multicolumn{3}{|c|}{$\mu g P / m l$ plasma } & $\%$ & $\%$ & $\%$ \\
\hline \multirow[t]{5}{*}{6} & G.C. & 118 & plasma & 26.1 & 29.5 & 60.0 & 22.6 & 25.5 & 51.9 \\
\hline & & 17.1 & $<1.019$ & 0.8 & 3.0 & 10.0 & 6.1 & 21.8 & 72.1 \\
\hline & & 48.8 & $<1.063$ & 4.7 & 14.3 & 30.0 & 10.1 & 28.8 & 61.1 \\
\hline & & 29.7 & $>1.063$ & 3.0 & 4.0 & 19.2 & 11.4 & 15.4 & 73.2 \\
\hline & & 31.7 & $1.019-1.063$ & 3.8 & 11.3 & 20.0 & 11.0 & 32.1 & 56.9 \\
\hline \multirow[t]{3}{*}{9} & H.C. & 187 & plasma & 21.6 & 54.8 & 106.0 & 11.8 & 30.0 & 58.2 \\
\hline & & 106 & $<1.063$ & 9.6 & 38.7 & 57.7 & 9.1 & 36.5 & 54.4 \\
\hline & & 28.8 & $>1.063$ & 1.7 & 3.5 & 23.7 & 5.9 & 12.0 & 82.1 \\
\hline \multirow[t]{14}{*}{11} & B.W. & 262 & plasma & 41.8 & 57.8 & 140.0 & 17.5 & 24.1 & 58.4 \\
\hline & & 145 & $<1.063$ & 18.9 & 26.3 & 82.5 & 14.8 & 20.6 & 64.6 \\
\hline & & 35.1 & $>1.063$ & 1.9 & 4.1 & 23.8 & 6.4 & 13.6 & 80.0 \\
\hline & \multirow{6}{*}{$\begin{array}{c}\text { Normal subjects } \\
\text { W.N. }\end{array}$} & & & & & & & & \\
\hline & & 94.3 & plasma & 6.7 & 15.5 & 53.0 & 8.9 & 20.6 & 70.5 \\
\hline & & 7.4 & $<1.019$ & 0.59 & 1.73 & 4.73 & 8.4 & 24.6 & 67.0 \\
\hline & & 37 & $<1.063$ & 2.52 & 11.1 & 23.8 & 6.7 & 29.7 & 63.6 \\
\hline & & 24.3 & $>1.063$ & 3.28 & 2.8 & 17.2 & 14.1 & 12.0 & 73.9 \\
\hline & & 29.6 & $1.019-1.063$ & 1.93 & 9.4 & 19.1 & 6.3 & 30.9 & 62.8 \\
\hline & W.N.* & 88 & plasma & 11.9 & 15.1 & 49.8 & 15.5 & 19.7 & 64.8 \\
\hline & & 13.2 & $<1.019$ & 1.0 & 2.9 & 8.1 & 8.1 & 24.3 & 67.6 \\
\hline & & 47.7 & $<1.063$ & 3.6 & 9.0 & 30.7 & 8.3 & 20.8 & 70.9 \\
\hline & & 35.3 & $>1.063$ & 6.0 & 3.9 & 22.7 & 18.3 & 12.0 & 69.7 \\
\hline & & 34.5 & $1.019-1.063$ & 2.6 & 6.1 & 22.6 & 8.3 & 19.6 & 72.1 \\
\hline
\end{tabular}

* Sample obtained from nonfasting subject showing an increase in level and percentage of lysolecithin in plasma but lower values for these in $\mathrm{D}<1.063$ than are shown by the abnormal plasmas.

abnormality was observed, consisting of an increase in the percentage of lysolecithin and sphingomyelin, and a decrease in the percentage of lecithin. For convenience, the samples have been separated into two groups, $\mathrm{A}$ and $\mathrm{B}$. Under group $\mathrm{A}$ are listed those samples that showed the abnormalities mentioned above in all three major phosphatides, while under group B are listed the samples in which one or more of the major phosphatides were normal in proportion. Wherever abnormalities did occur in group B, they were in the same direction as those in group A. Although divided into two groups, the set of samples actually presented a spectrum of abnormality ranging in degree of severity from marked in some samples of group A, through minimal in many samples of group B, to two samples which had entirely normal proportions. The degree of abnormality in the proportions among the major phosphatides listed in Tables I and II was not related to the levels of total lipid, cholesterol, or chloroformsoluble phosphorus, or to the degree of lactescence of the plasma.
Ranges of normal values presented in the previous paper are listed at the bottom of Table I for comparison.

Distribution of major phosphatides in lipoprotein classes. Plasma samples 6 and 9 of group A, sample 11 of group $B$, and two normal samples were separated into density classes by ultracentrifugation. The phosphatide compositions of the density classes were determined in order to ascertain in which class the abnormal proportions occurred. The values obtained are listed in Table III.

The recovery of phosphorus in the density classes was relatively low, due probably to incomplete re-extraction of lipid by chloroform from the large amount of inorganic residue present in the methanol-chloroform extract of the density classes. Comparison of the levels of each phosphatide in the density classes with its level in plasma reveals that the loss of lecithin was least, while that of lysolecithin was greatest. In spite of this, the abnormal phosphatide relationship manifest in whole plasma still appeared in the 
density classes, at $\mathrm{D}<1.063$ in each instance, and in the class D 1.019-1.063 when the contents of that class could be satisfactorily calculated.

Minor phosphatide components. The phosphatides of two group A plasmas and of three group $B$ plasmas were also analyzed by combined quantitative column and paper chromatography. The results of these five analyses confirmed the presence of the abnormalities in proportions that had been found among the major phosphatides by quantitative paper chromatography. In addition, the minor phosphaticles were analyzed. The sum of phosphatidylethanolamine plus lysophosphatidylethanolamine was determined in four samples and was present at the concentrations of 0.3 to 1.3 $\mu \mathrm{g} \mathrm{P}$ per ml plasma and constituted 1.1 to 2.4 per cent of the sum of the three major plus the three minor phosphatides. Inositol phosphatide was determined in three samples, was present at the concentration of 0.1 to $0.4 \mu \mathrm{g} \mathrm{P}$ per ml plasma, and constituted 0.3 to 0.9 per cent of the sum of the six phosphatides. Values obtained for the three minor phosphatides of plasma from normal subjects and patients with several disease states, which were presented in the preceding paper (9), indicate that the concentrations of these phosphatides lie within relatively narrow ranges. Within these narrow ranges, the existence of significantly different means for the normal subjects and for patients with the nephrotic syndrome can be neither proven nor disproven until many more data are gathered. In all other samples, the minor phosphatides have been investigated qualitatively. Inositol phosphatide has been detected in every sample by veiwing the paper chromatogram under ultraviolet light after staining with rhodamine 6G. Lysophosphatidylethanolamine has been detected in many, but not all, samples and phosphatidylethanolamine has been detected in all but two samples ( 1 and 2 ) by a ninhydrin test on the paper chromatogram.

Correlation of clinical findings with plasma phosphatide abnormalities. Percutaneous renal biopsy was performed on all patients except M.L. and B.W. The biopsy findings and plasma phosphatide analyses are summarized in Table IV. All untreated subjects who have shown no glomerular change on biopsy and no clinical progression to chronic nephritis have had a group A phosphatide pattern (F.G., G.C., H.C., D.C.), whereas those patients who have had only a group $B$ pattern have had evidence of underlying glomerular clisease (L.A., L.C.). Transition from a group $\mathrm{A}$ to a group B pattern has occurred with successful steroid therapy (D.C.), with an indeterminate clinical course without steroid therapy (J.S.), and with progression to chronic nephritis (E.J.). Whether these patterns will be seen in future cases is conjectural.

\section{DISCLSSION}

Although many studies have been carried out, the etiology of the abnormalities seen in the circulating lipids in the nephrotic syndrome has not

TABLE IV

Correlation between phosphatide analyses and findings on percutaneous renal biopsy

\begin{tabular}{|c|c|c|c|c|c|}
\hline Plasma & Patient & Date & $\begin{array}{l}\text { Phosphatide } \\
\text { abnormality } \\
\text { Group }\end{array}$ & Date of biopsy & Biopsy report* \\
\hline 1 & F.G. & $2 / 59$ & A & $2 / 59$ & No glomerular change \\
\hline 6 & G.C. & $12 / 59$ & A & $7 / 58$ & No glomerular change \\
\hline 9 & H.C. & $3 / 60$ & $\mathrm{~A}$ & $3 / 60$ & No glomerular change \\
\hline 5 & M.D. & $5 / 60$ & $\mathrm{~A}$ & $4 / 60$ & Membranous glom. change \\
\hline 4,17 & D.C. & $4 / 59,8 / 59$ & $\mathrm{~A}$ & $8 / 59,8 / 60$ & No glomerular change \\
\hline 18,19 & D.C. & $7 / 60,8 / 60$ & $\mathrm{~B}$ & & \\
\hline 20,21 & D.C. & $8 / 60,8 / 60$ & B & & \\
\hline 2 & E.J. & $2 / 59$ & $\mathrm{~A}$ & $2 / 59$ & Membranous glom. change \\
\hline $22,23,24$ & E.J. & $4 / 59,4 / 59,6 / 59$ & $\mathrm{~B}$ & $9 / 59$ & Chronic glomeruloneph. \\
\hline 3 & J.S. & $12 / 58$ & A & $11 / 59$ & Membranous glom. change \\
\hline 16 & J.S. & $9 / 59$ & $\mathrm{~B}$ & & \\
\hline 14 & L.A. & $6 / 59$ & B & & \\
\hline 10 & L.A. & $8 / 59$ & $\mathrm{~B}$ & $8 / 59$ & Subacute glomeruloneph. \\
\hline 15 & L.C. & $8 / 59$ & B & & \\
\hline 13 & L.C. & $9 / 59$ & B & $10 / 59$ & Acute glomeruloneph. \\
\hline
\end{tabular}

* All biopsies showed tubular changes compatible with nephrosis. 
as yet been elucidated. Some investigators have felt that the increase in concentration of plasma lipids may be related to an inadequate "clearing mechanism," due chiefly to hypoalbuminemia, since, in subjects with the nephrotic syndrome, plasma lipid levels are reduced after intravenous infusions of albumin (11). However, quantitative changes in the production or removal of normally constituted circulating lipids seem inadequate to explain the phenomena that are observed. Since the increased concentration of lipids is apparently confined to the vascular compartment, and perhaps to the liver (12) and since the plasma lipids in the nephrotic syndrome can be influenced by certain factors which produce changes in them in normal subjects (13), the postulation of a "trapping effect" due to abnormalities in the plasma lipoproteins themselves has seemed reasonable. This was originally proposed by Byers, Friedman and Rosenman (14), and subsequently given experimental support by them (15).

There are two pieces of evidence which may be interpreted to mean that the lipoproteins of the serum in the nephrotic are abnormal. The first relates to the electrophoretic studies of Kunkel and Slater (3), and the second issues from the ultracentrifugal analyses of Baxter and colleagues (7).

Kunkel and Slater studied the lipoprotein pattern of hyperlipemic sera by zone electrophoresis. In childhood nephrosis they observed that $\alpha$-lipoprotein was markedly reduced, $\beta$-lipoprotein was absent, and that there were two or three irregular peaks between the $\alpha$ and $\beta$ positions. These peaks might have resulted from poor separation of the $\alpha_{2}$ from the $\beta$-globulin (16), due partially to excess binding of free fatty acids to the $\beta$-lipoproteins (17), or they might have been partially due to abnormalities in the lipoproteins themselves. The ultracentrifugal analyses of Baxter and colleagues (7) have revealed abnormal proportions among the lipid constituents of individual lipoprotein fractions of nephrotic serum, which demonstrate that these lipoprotein fractions are not normal within themselves.

The marked disturbance in the nephrotic syndrome in the relationship among the plasma phosphatides reported in this paper, together with the finding that this is at least partially due to the similar disturbances within lipoprotein classes, adds additional evidence that lipoproteins themselves are abnormal in this condition, and thus reinforces the basis upon which to build a theory of "trapping" to explain the development and maintenance of increases in the plasma lipid levels that are observed in the nephrotic syndrome.

If alterations in the rates of synthesis of individual phosphatides do occur, as is postulated, one may speculate on what metabolic changes might be responsible for this. The normal metabolic pathways for the individual phosphatides are not as yet completely worked out in experimental animals, and have not been extensively studied in human beings. Fishler, Entenman, Montgomery and Chaikoff (18) have demonstrated that $\mathrm{P}^{32}$ inorganic phosphate is not converted to phospholipid in hepatectomized dogs, and that, when the liver is excluded from the circulation of the dog, the rate of disappearance of $\mathrm{P}^{32}$-phospholipid is greatly prolonged. The livers of various animals have been found to contain all of the phosphatides that have been identified in human plasma (19). Enzyme systems have been prepared from liver that catalyze the formation of lecithin from diglyceride and cytidine diphosphate choline (20), of phosphatidylethanolamine from diglyceride and cytidine diphosphate ethanolamine (20) (both of these occur with the same enzyme), of sphingomyelin (in the form of a stereoisomer of the naturally occurring compound) from a ceramide and cytidine diphosphate choline (21), and of lecithin from lysolecithin (22).

Suppression of the conversion of lysolecithin to lecithin, and of diglyceride to lecithin and phosphatidylethanolamine, with diversion of phosphorylcholine to sphingomyelin, and of diglyceride to triglyceride, would make available to the plasma altered amounts of the phosphatides which would be compatible with the abnormal proportions found among the individual phosphatides in the plasma of patients with the nephrotic syndrome.

\section{SUM M ARY}

The plasma phosphatides lysolecithin, sphingomyelin, and lecithin have been quantitatively analyzed by silicic acid chromatography in patients with the nephrotic syndrome, and an abnormality consisting of a higher proportion of lysolecithin and sphingomyelin, and a lower proportion of lecithin, has been found. 
In the most markedly abnormal plasmas, all three of the above changes were found, while in the less abnormal plasmas, one or two of these changes were found, the remaining phosphatides being present in normal proportion. On fractionation of three abnormal plasmas by ultracentrifugation, an abnormality in phosphatide distribution was found in the low-density classes in each case. The degree of abnormality was not related to the levels of total lipid, cholesterol, or chloroform-soluble phosphorus, or to the serum albumin levels, nor could it be absolutely correlated with renal biopsy findings or with the clinical course in all cases. However, the demonstration of this abnormality in plasma and in lipoprotein classes is further evidence of the abnormal constitution of lipoproteins in the nephrotic syndrome.

\section{REFERENCES}

1. Nye, W. H. R., Waterhouse, C., and Marinetti, G. An abnormal plasma phospholipid pattern in the nephrotic syndrome. Clin. Res. 1959, 7, 278.

2. Nye, W. H. R., and Waterhouse, C. An abnormality in the phospholipid pattern of whole plasma and of a lipoprotein fraction in the nephrotic syndrome. Clin. Res. 1960, 8, 244.

3. Kunkel, H. G., and Slater, R. J. Lipoprotein patterns of serum obtained by zone electrophoresis. J. clin. Invest. 1952, 31, 677.

4. Grabar, P. The study of the normal and pathological constituents of the blood by immuno-electrophoretic analysis. Triangle 1960, 4, 185.

5. Barr, D. P., Russ, E. M., and Eder, H. A. Protein-lipid relationships in human plasma. II. In atherosclerosis and related conditions. Amer. J. Med. 1951, 11, 480.

6. Havel, R. J., Eder, H. A., and Bragdon, J. H. The distribution and chemical composition of ultracentrifugally separated lipoproteins in human serum. J. clin. Invest. 1955, 34, 1345.

7. Baxter, J. H., Goodman, H. C., and Havel, R. J. Serum lipid and lipoprotein alterations in nephrosis. J. clin. Invest. 1960, 39, 455.

8. Moser, H. W., and Emerson, K., Jr. Estimation of the phospholipid phosphorus turnover time in man: Studies in normal individuals, in patients with the nephrotic syndrome and in other types of hyperlipemia. J. clin. Invest. 1955, 34, 1286.

9. Nye, W. H. R., Waterhouse, C., and Marinetti, G. V. The phosphatides of human plasma. I. Normal values determined by paper and column chromatography. J. clin. Invest. 1961, 40, 1194.

10. Bloor, W. R. The determination of cholesterol in blood. J. biol. Chem. 1916, 24, 227.

11. Baxter, J. H., Goodman, H. C., and Havel, R. J. Hyperlipidemia of nephrosis (abstract). J. clin. Invest. 1957, 36, 873.

12. Marsh, J. B., and Drabkin, D. L. Metabolic channeling in experimental nephrosis. V. Lipide metabolism in the early stages of the disease. J. biol. Chem. 1958, 230, 1083.

13. Baxter, J. H., Goodman, H. C., and Shafrir, E. Effects of glucose infusions on serum lipids and lipoproteins in nephrosis (abstract). J. clin. Invest. 1959, 38, 986.

14. Byers, S. O., Friedman, M., and Rosenman, R. H. Review: On the regulation of blood cholesterol. Metabolism 1952, 1, 479.

15. Friedman, M., Roseman, R. H., and Byers, S. O. Lipid and cholesterol content of hepatic lymph in experimental nephrosis. Amer. J. Physiol. 1957, $190,180$.

16. Swahn, B. Studies on blood lipids. Scand. J. clin. Lab. Invest. 1953, 5, suppl. 9.

17. Shafrir, E. Partition of unesterified fatty acids in normal and nephrotic syndrome serum and its effect on serum electrophoretic pattern. J. clin. Invest. 1958, 37, 1775.

18. Fishler, M. C., Entenman, C., Montgomery, M. L., and Chaikoff, I. L. The formation of phospholipid by the hepatectomized dog as measured with radioactive phosphorus. Site of formation of plasma phospholipids. J. biol. Chem. 1943, 150 47.

19. Marinetti, G. V., Witter, R. F., and Stotz, E. The incorporation in vivo of $\mathrm{P}^{32}$-labeled orthophosphate into individual phosphatides of rat tissues. J. biol. Chem. 1957, 226, 475.

20. Kennedy, E.P., and Weiss, S. B. The function of cytidine coenzymes in the biosynthesis of phospholipides. J. biol. Chem. 1956, 222, 193.

21. Sribney, M., and Kennedy, E. P. The enzymatic synthesis of sphingomyelin. J. biol. Chem. 1958, 233, 1315.

22. Marinetti, G. V., Erbland, J., Witter, R. F., Petix, J., and Stotz, E. Metabolic pathways of lysolecithin in a soluble rat-liver system. Biochim. biophys. Acta 1958, 30, 223. 